\title{
EXISTENCE OF REGIONAL REGULATION NUMBER 12 OF 2012 TO THE COMPLETION OF VIOLENCE ON CHILDREN IN BEKASI CITY, INDONESIA
}

\author{
Jaya Eko Setyawan \\ Student Master of Law \\ Universitas Krisnadwipayana Jakarta \\ Indonesia \\ Erna Widjajati \\ Professor \\ Faculty of Law \\ Universitas Krisnadwipayana Jakarta \\ Indonesia \\ Philips A. Kana \\ Lecturer \\ Faculty of Law \\ Universitas Krisnadwipayana Jakarta \\ Indonesia
}

\section{ABSTRACT}

This study aims to analyze issues related to the settlement of child abuse according to Bekasi City of Regional Regulation No. 12 of 2012 as well as understand the existence of the law is in the order of national legislation. This is a descriptive analytical study with normative juridical approach. The results showed that there effort completion violence against children set in Bekasi City Regional Regulation No. 12 of 2012 on Chapter XII of the Protection of Women and Children From Violence, Trafficking and Exploitation through prevention of violence against women and children, including trafficking in persons, elimination of all forms of violence and exploitation of women and children; protect from discrimination against women and children, protection from neglect and other abuses; providing services to women and children victims of violence, the complainant and witnesses; facilitate and mediate on disputes households to achieve domestic unity harmonious and prosperous.

\section{Keywords: Protection of Children, Violence Against Children, Perda.}

\section{Introduction}

See very child in the world has the freedom since birth. Freedom is gaining recognition of human rights, the freedom of children are protected by state law and must not be obliterated or removed by anyone. The child remains a child inherent nature of nonprivate; need love and protection of the rights of parents, community, and country. Article 1 of the UN Convention on the Rights of the Child (1989) defines a child as: "Any person under the age of 18 years unless under the law applicable to the child majority is attained earlier." (United Nations General Assembly, 1989) Meanwhile, according to the ILO definition of a child is any person below the age of 18 years.

Kids are an integral part of the survival of the nation. Relating to the position of children who have a strategic role, then Country guarantee in the constitution of every child's right to live, grow, develop, and protection from violence and discrimination (UUD, 1945).

Violence against children is a common thing we hear from the media and social media today. Violence against children is carried out by people who are supposed to protect and love them as parents, teachers, relatives, neighbors and so on. Every year, cases of violence against children continue to occur, various locations and environments, even going on and carried by people nearby. In general violence or child abuse is an act that hurt or harms a child. For acts of violence against children by parents is usually a symptom of irregularities in parenting, and reinforced by other family problems such as poverty, entangled alcohol and drugs, or involved in antisocial behavior. 
Based on data from the Integrated Service Center for Women and Children (P2TP2A), West Java found as many as 240 cases of child abuse throughout 2015 and as many as 346 cases of child abuse in 2016 (Prime, 2017). Furthermore, based on data reported by metrotvnews.com found that as many as 328 cases of child abuse in 2017 which showed a high level of violence? Some forms of violence against children that occurred was sexual harassment, domestic violence and neglect (Mutakin, 2018).

Based Commissioner for Child Protection Commission (KPAI) Education reported Kabar3.com recorded that there are 24 counties and cities in Indonesia with the highest number of complaints on child abuse. For West Java province, most are Bogor, Bandung, and Bekasi (Akbar, 2018).

Bekasi city is one of the cities with the winning title of "City for Children 'at the intermediate level. Based on the title, it should Bekasi city have adequate facilities in terms of providing comfort and safety for the child. This is also consistent with the policy of Bekasi City Government to increase the budget Activities Improvement of Child Protection and Assistance Cases Children issues in the Office of Women's Empowerment and Child Protection Bekasi City that is Rp 225,000,000, -in 2016, and increased by 57.7\% to Rp 355.000.00, -in 2017 and increased by $12.67 \%$ in 2018 with a total budget of Rp 400,000,000, -.Thus, from 2016 to 2018 there has been a budget increase of 77.77\%. However,

Regional Indonesian Child Protection Commission (KPAID) Bekasi, recorded 198 cases of violence against children throughout 2017. The figure was higher than in 2016, ie as many as 127 cases. In 2017 occurred 198 cases of child abuse, it is known that the Bekasi City Government has done one advocacy services in the form of diversion, the resolution of cases without a judicial path.

With the increasing acts of violence against children from year to year, shows that the need for action from parents, teachers, communities, and governments to make efforts to protect children. Children should acquire a safe and comfortable environment in the family and the school, but it turns out the cases in the mass media can be seen that even more children become victims of violence at home and school.

The concept of "Child Protection" refers to Article 1 (2) of Law No. 35 of 2014, which states that "Child Protection are all activities to ensure and protect children and their rights in order to live, grow, develop, and participate optimally in accordance with human dignity, and protection from violence and discrimination ". Thus, the meaning of statutory protection is not merely to protect children from the risks of violence exploitation or neglect, but more than that because the protected are the basic rights of children (Bappenas, 2015).

The Government of Bekasi city in this regard have also been issued Regional Regulation No. 12 of 2012 on the Protection of Women Children contained in Article 1 (9) that "the protection of children are all activities to ensure and protect children and their rights in order to live, grow, develop and participate, optimally in accordance with human dignity and protection from violence and discrimination ".

In the prevention and treatment of child abuse in Bekasi, there are technical and operational units engaged in the area of child protection, namely P2TP2A (Integrated Services Center for Women and Children). P2TP2A himself has made a number of preventive and curative services in the prevention and treatment of child abuse. Therefore, with the Regional Regulation No. 12 of 2012 and has the integrated technical services unit as P2TP2A why child abuse in Bekasi tends to be high and increased from year to year.

The reason for choosing the jurisdiction of Bekasi City Government as taking place in the study population is in this region is still quite a high number of violence against children (data 2016 with 127 cases and in 2017 with 198 cases). With the publication of Bekasi City Regional Regulation No. 12 of 2012, is expected to decrease child abuse each year. As Article 21 paragraph (4) of Law Number 35 Year 2014 regarding the amendment of Law No. 23 of 2002 regarding Child Protection states that "In order to ensure the fulfillment of children's rights and implement the policy referred to in paragraph (3), Local Authorities have the duty and responsibility to implement and support national policies in the delivery of child protection in the region. 


\section{Literature Review \\ The scope of the Child}

According to Big Indonesian Dictionary (KBBI) is a descendant or child is a human being who is still small. (KBBI, 1990). Meanwhile, in the everyday sense is the child is not yet reached a certain age or unmarried; this notion is often used as a general guideline. When viewed from the judicial aspect, the definition of a child in the eyes of Indonesian laws commonly defined as persons who are minors, minors or minors or circumstances often also referred to as a child under the supervision of a guardian (Mulyadi, 2005).

There are several laws that apply in Indonesia at this time regulating the definition of children by age. The age limit someone still in the category of children, based on some of the existing regulations in Indonesia is quite diverse, among others, namely:

1. Article 1 (1) of the Act 3 of 1997 on Juvenile Justice, states that a child is a person who in the case of naughty children have reached the age of 8 (eight) years but has not reached 18 (eighteen) years old and had never been married;

2. Article 1 paragraph 5 of Act 39 of 1999 on Human Rights, said that child means every human being below the age of 18 (eighteen) years old and unmarried, including an unborn child if it is for the sake of his interest;

3. Article 1 (1) of Act 35 of 2014 states, a child is someone under 18 (eighteen) years, including an unborn child.

\section{Legal Protection on Children}

In Big Indonesian Dictionary, protection comes from the hedge which means protect, prevent, maintain and fortify. While Protection means conservation, maintenance, custody, asilun, and bunkers. Legal protection is a protection afforded to legal subjects in the form of either preventive or devices that are reversed, both oral and written.

Child protection in Law No. 35 of 2014 on Child Protection is defined as all activities to ensure and protect the child and the human right children in order to live, grow, develop and participate optimally in accordance with human dignity and protection from violence and discrimination. Getting protection is the right of every child, and the accomplishment of protection for a child means the realization of justice in a society.

That protecting the child is essential to protect the family, community, nation, and state in the future. The importance of child protection for the sake of the future of a community, whether that community smallest of the family, which is the largest community or that State. That is, with to effort protection for the children of these communities not only to uphold the rights of children but also at the same time invests for their life in the future. Child protection is an effort that held the circumstances that enable the implementation of children's rights and obligations are protected human child.Ini means to acquire and retain the right to life, has survival, growth and development and the protection of their rights and obligations in the implementation of its own or together with protectors, Juridical protection or better known as legal protection. According to Arief is a safeguard against various freedom of law and the rights of the child as well as the various interests related with child welfare (Irma, 1990).

Child protection in criminal law, other than provided for in Article 45, Article 46, and Article 47 of the Criminal Code (has been revoked by regulation Act 3 of 1997 on Juvenile Justice). Then there are also some Articles that are directly or indirectly related to the protection of children which include Article 278, Article 283, Article 287, Article 290, Article 301, Article 305, Article 308, Article 341 and Article 365 of the Criminal Code. Subsequently, in Act 35 of 2014 on Child Protection on the principle governing the protection of child rights. In Act 4 of 1979 regarding Child Welfare. As discussed earlier, various efforts to protect another child not to be oriented in an attempt to create a child's welfare. To achieve these objectives,

1. Principles of Non-discrimination

2. The principle of the best interests of the child 


\section{The principle of the rights of children to live, survive and development}

4. The principle of respect for the views of children

Furthermore, Article 3 of Law 23 of 2002 on Child Protection stipulates that child protection aims to ensure the fulfillment of children's rights in order to live, grow, develop and participate optimally in accordance with human dignity, and protection from violence and discrimination, in order to achieve quality of Indonesian children, noble, and prosperous. Act 35 of 2014 on the Amendment of Act No.23 of 2002 on Child Protection also establishes special protection to children in conflict with the law. Special protection to children in conflict with the law in the realm of criminal law given to children who are victims of crime, witnesses, and perpetrators of criminal acts. Regarding special protection to children victims of violence provided for in Article 69 of Law 35 of 2014 on the Protection of the Child which states that special protection for child victims of violence as referred to in Article 59 include physical, psychological, and sexual achieved through efforts:

1. Dissemination and socialization of the provisions of the legislation that protects children victims of violence; and

\section{Monitoring, reporting and sanctioning.}

The government as mandated by Act 23 of 2002 on Child Protection has established the Indonesian Child Protection Commission (KPAI) to provide protection to children in Indonesia. Where this as stipulated in Article 74 of Law 35 of 2014 on the Protection of the Child which states that in improving the effectiveness of the implementation of child protection, with this legislation established the Indonesian Child Protection Commission is an Independent. And in the case of necessary, local governments can establish local child protection commission or similar institution to support the implementation of child protection surveillance area.

Article 76 of Law No. 35 of 2014 on Child Protection stipulates that the Indonesian Child Protection Commission in charge:

1. To supervise the implementation of the protection and fulfillment of children's rights;

2. Provide input and proposal of formulation of policy for the protection of children;

3. Collect data and information on child protection;

4. Receive and conduct a review of public complaints about violations of the rights of children;

5. Intervening on violations of children's rights;

6. Cooperating with public institutions established the field of child protection; and

7. Providing a report to the authorities about the existence of a violation of this Act.

\section{Violence on Children}

Violence in various forms the motif of some behaviors Indonesian culture that until now the mainstream that reduced values national identity and gives the impression of how climate solideritasan humans has not been fully able to have a personality introspective political, economic and social personality of the nation and give an impression of how climate solideritasan humans has not been fully able to have a personality introspective politically, economically and socially. M. Marwan and Jimmy stated that violence is nature or characterized by hard, resulting in injury or death of another person damage physical, or goods or coercion (Magfur, 2003).

Violence has usual in the daily life of our society. Conflict resolution is always accompanied by acts of violence. The acts of violence that often occurs not only done by individuals as members of society, but also by the state. Galtung (2003) violence typology divides into three (3) ie direct violence, cultural violence, and structural violence. Direct violence is an event. Structural violence is a process; whereas cultural violence is something that is permanent. The third typology of this violence to enter time differently, which is analogous to the difference in theory between the earthquakes as an event (direct violence), the movements of tectonic plates as a process (structural violence). 
This condition leads to a violence strata image phenomenology of violence. Cultural violence is the most basic level and is a source of inspiration for structural violence and direct violence. The next stratum of structural violence in the form of rhythms violence local and the patterns of cultural violence. Peak, violence appears to the eye in the form of direct violence committed by men against another.

Direct violence manifests in behavior, such as murder, beatings, intimidation, torture. Violence structural or institutionalized violence manifests in context, systems, and structures, such as discrimination in education, jobs, health care. Cultural violence manifests itself in attitudes, feelings, values adopted in the community, for example, hatred, racism, intolerance (Galtung, 2003).

According to the nature of violence, there are two (2) that personal violence and structural violence. Personal violence is dynamic, easily observed, showing great fluctuations that can cause structural changes while violence in static, showing certain stability and does not appear. Structural violence takes such forms of exploitation, fragmentation of society, the destruction of solidarity, the penetration of outside forces that eliminate the autonomy of the community, and the marginalization of the community thus eliminating public participation in making decisions about their own destiny. This structural violence also creates poverty, inequality in income and wealth, social injustice, and alienation or elimination of the individual as proses uniformity of citizens (SIH, 2005).

Violence on children is caused by several factors that influence it. Factors that influence is so complex, as described by Suharto, violence against children is generally caused by internal factors are derived from their own children as well as external factors are derived from the condition of the family and society, such as:

1. The child has a disability, behavior disorders, autism, child ignorance of their rights; children are dependent on adults;

2. Family poverty, parents are unemployed, the income is not enough, many children;

3. Single or multiple families' broken (Broken Home);

4. Family psychologically immature, ignorance educate children, parents' expectations are unrealistic, unwanted children, children born out of wedlock;

5. Severe illness or mental disorders in one or both parents. Mental disorders in the elderly can also hold the role of the causes of abuse or neglect of children because of thought patterns or decisions of a parent to be disturbed;

6. The history of child neglect. Parents who suffered abuse as a child tend to treat one of the children.

7. Poor social environment, the slums, the displacement of children's playground, indifference to the actions of exploitation, the views of the child values that are too low.

\section{Legal Certainty}

Certainty is a matter of (state) for sure. Intrinsically law must be certain and fair. Legal certainty is a question that can only be answered normatively not sociology. Normative Legal Certainty it is when a rule is made and enacted exactly as set definitely and Logical (Kansil, 2009).

Rule of Law as one purpose of the law and could be said efforts to bring about justice. The real form of the rule of law is the implementation and enforcement of action regardless of who is doing. Legal certainty anyone can predict what will happen if the legal action, certainty is needed to achieve justice. Certainty one feature that cannot be separated from the law, especially to the norm.

Obviously in the sense not raise doubts (multi-interpretation) and logical in the sense of becoming a system of norms the other norms that do not clash or conflict Norma. Legal certainty refers to the application of the law clear, precise, consistent and consequently that its implementation cannot be influenced by circumstances subjective nature. Law is a collection of rules or principles in life together; the overall rules of conduct that apply to a life together can 
be forced to implement the sanction. Legal certainty is a characteristic that cannot be separated from the law, especially for written legal norms.

The laws enforced by the law enforcement agencies must ensure "legal certainty" for the sake of order and justice in society. Legal uncertainties will cause chaos in the life of society and each other do as well as acts of vigilantism. Things like this make life are in "social disorganization or social chaos".

The legal protection of children from violence can be seen in Article 80 of Law No.23 of 2002 on Child Protection as follows:

1. Anyone committing atrocities, violence or threats of violence, or child abuse shall be punished with imprisonment of three (3) years and 6 (six) months and/or a maximum fine of Rp 72,000,000.00 (seventy-two million).

2. In the case of the child referred to in subsection (1) serious injury, the offender shall be punished with imprisonment of 5 (five) years and/or a fine of Rp 100,000,000.00 (one hundred million rupiahs).

3. In the case of the child referred to in subsection (2) dies, the offender shall be punished with imprisonment of ten (10) years and/or a fine of Rp200.000.000,00 (two hundred million rupiah).

4. Criminal plus one-third of the provisions referred to in paragraph (1), (2) and (3) if the conduct of the persecution of his parents.

\section{Article 80 of Law No. 35 of 2014 on Protection of Children, as follows:}

1. Any person who violates the provisions in Article 76C shall be punished with imprisonment of three (3) years and 6 (six) months and/or a maximum fine of Rp. 72,000,000.00 (seventy two million).

2. In the case of children, as mentioned in paragraph (1) serious injury, the offender shall be punished with imprisonment of 5 (five) years and/or a fine of $\mathrm{Rp} \mathrm{100,000,000.00} \mathrm{(one} \mathrm{hundred} \mathrm{million} \mathrm{rupiah).}$

3. In the case of children as mentioned in paragraph (2) dies, the offender shall be punished with imprisonment for a period of 15 (fifteen) years and/or a fine of Rp3.000.000.000,00 (three billion rupiah).

4. Criminal plus one-third of the provisions referred to in paragraph (1), (2) and (3) if the person who committed abuses His parents.

\section{Research Methods}

\section{Research Design}

The method used in this research is the socio-juridical or legal research nondoctrinal namely by constructing the law as a reflection of public life itself that emphasis on searches, constancy-constancy empirical with the consequences in addition to referring to the law is written also organizes observation of right behavior -Right occur (Soemitro, 1988). Spesifikasi study in this research is descriptive, which describes the applicable laws and regulations associated with law theories and practices concerning the implementation of positive law issues relevant to the purpose of this study. Aiming to obtain a description of the application of the legal protection of the rights of the child (Soemitro, 1988).

\section{Objects and Sample Research}

The Research made the region the City of Bekasi and research materials are of the authorities include, Head of the Women and Children Protection Bekasi, Child Protection Commission Bekasi, P2TP2A Bekasi, District Court Judge Bekasi, Attorney State Attorney Bekasi City and Advocate in the region District Court law Bekasi.

\section{Sampling Technique}

The method of selecting the informants in this election was originally purposive sampling pointing at the Department of Women and Children Protection Bekasi, Board P2TP2A Bekasi City (sampling intended) is 
formulated as a technique of selection of sources on the ground in accordance with the purposes and research problems and is considered sufficient if all the data required is already collected. Selection of the next informant using snowball sampling. Selection of informants with this new method stops when had not found any new information. Use of Snowball sampling necessary for in-depth data mining and the maximum can be obtained, given that the problems in this study relate to the role of Bekasi City Government in the protection of children.

\section{Method of Collecting Data}

Sources of data that are used are primary data. Primary data is data that originates in the words of informants in answering the question which is based on the individual.

The means used to test the validity, legality or correctness of the data that has been collected in this research is by using triangulation. Triangulation methods used were: (Moleong, 1991):

a) Triangulation source, to test the credibility of the data is done by checking the data with different sources;

b) Triangulation method, which is to test the credibility of the data is done by checking the data using different data collection techniques;

c) Triangulation of time, to test the credibility of the data is done by checking the data using different data collection time.

\section{Data Analysis Method}

The data collection method used in this research is the collection of data obtained and analyzed by descriptive qualitative, that explain or elaborate on existing data to determine the suitability of these data with the existing regulations in the practice run. Data analysis was performed through data reduction, which is carried out by means of abstraction. Abstraction is a summary core business, processes, and statements that need to be maintained so that it remains therein. The next step is arranged in units, the units were then categorized in the next step. Categories that were made while coding. The final stage of this data analysis is examining the validity of the data (Sugiyono, 2008).

\section{Results and Discussion}

\section{A. Completion Violence in Children According to Bekasi City Regional Regulation No. 12 of 2012.}

Act No. 23 of 2002 as amended by Law No. 35 of 2014 on the protection of children has been asserted that the responsibility of parents, families, communities, governments, local authorities, and the State is a series of activities carried out continuously for the sake of protection of children of violence. The series of activities are to be sustainable and directed to ensure the growth and development of children, whether physical, mental, spiritual and social. This action was intended to realize the best life for children who are expected as a potential successor to the nation, though, and have a spirit of nationalism inspired by the nobility and the values of Pancasila, and willed hard guard unity and integrity of the nation.

Completion of violence against children has had a comprehensive regulation from the Law until regulations implementing such legislation and regulation guidelines set out in the regulations of the mayor. In Hierarchical background issuance of Law No. 23 of 2002 (BAL) on the protection of children is due to the State of Indonesia which ensures the well-being of each of its citizens, including the protection of children's rights that constitute Human Rights as contained in the 1945 Constitution and the UN Convention on children's rights. UU no. 23 in 2002 and then renewed by Act 35 of 2014, the reasons to change and renewal for Law No.23 of 2002 has not been able to be a tool to prevent violence against children and protect children's rights.

Explanation of Law 23 of 2002 on the protection of children mentions though UUNo. 39 on Human Rights has been included on children's rights, implementation of the obligations and responsibilities of parents, families, communities, governments and the State to provide protection to children, they needed a law on child protection as a legal basis for the implementation of the obligations and responsibilities the. It is reiterated through Law No. 35 than 2014 using 1945 and the Convention on Rights of the Child ratified by the Indonesian government through Presidential Decree No. 36 of 1990. Through Law No. 35 of 2014, aim to provide protection on Indonesia children from all forms of discrimination and violence is emphasized. UU no. 352014 has added a definition of violence that previously did not exist in Law No. 23 of 2002. The purpose of the law on child protection is to protect children from 
violence all forms physical, emotional, social and sexual, neglect, acts of harm, exploitation; economic, sexual, and discrimination due to economic background, political, religious, social, cultural, and parents so that children's rights in order to live, grow, develop and participate optimally protected from violence and discrimination in order to realize Indonesian children qualified, and prosperous. actions harm, exploitation; economic, sexual, and discrimination due to economic background, political, religious, social, cultural, and parents so that children's rights in order to live, grow, develop and participate optimally protected from violence and discrimination in order to realize Indonesian children qualified, and prosperous. actions harm, exploitation; economic, sexual, and discrimination due to economic background, political, religious, social, cultural, and parents so that children's rights in order to live, grow, develop and participate optimally protected from violence and discrimination in order to realize Indonesian children qualified, and prosperous.

Child protection afforded by everyone either or age parents, families, communities, government and the state. Article 20 of Law No. 23 of 2002 as amended by Law No. 352014 defines: "state, the government, local governments, communities, families, and parents or guardians are obliged and responsible for the implementation of child protection." So, who seek the protection of a child is a member of the community according to his ability with a wide variety of situations and certain conditions. Every citizen takes responsibility for the implementation of child protection for the welfare of the child (Prakorso, 2013).

Children who are victims of domestic violence are categorized as children should get special protection under Article 59 of Law No. 23 of 2002 as amended by Law No. 35 of 2014 on the protection of children "of the government, local authorities and other state agencies are obliged and responsible to provide special protection to children in emergency situations, children in conflict with the law, children of the group minoritadan isolated, children exploited economically and / or sexual, trafficked children, children who are victims of drug abuse, alcohol, psychotropic and other addictive substances (drugs), child abduction, sale and trafficking, children victims of abuse both physically and / or mentally, children with disabilities,

To implement the protection of children on the child protection legislation also provides for public participation in protecting children, specifically in Article 72 paragraph (1): People participate in child protection, either individually or in groups. (2) the role of the public referred to in paragraph (1) carried out by individuals, child protection agencies, social welfare agencies, community organizations, educational institutions, mass media, and business entities (UU / 35, 2014).

Normatively Act 23 of 2002 as amended by Act No. 35 of 2014 has been set in a comprehensive and general, but in doing so requires implementing regulations are technical in nature. Then be made to Regulation Bekasi City of Regional Regulation No. 12 of 2012 as executive regulations. Starting from the preamble Regulation of Regional Bekasi City No. 12 of 2012 which reads: "to ensure and protect the rights of women and children to participate optimally in accordance with human dignity, as well as protection from violence, discrimination, and violation of rights women and other children,

Regulation of Bekasi City of Regional Regulation No. 12 of 2012 as a form of embodiment of the legislation is higher. The regulation also guarantees the rights of children include:

1. Civil rights and freedom;

2. Basic welfare (education and health);

3. Good parenting.

4. A safe and comfortable environment.

5. Special protection for children with special needs;

6. The right to adequate information;

7. The right to assistance;

8. Right on the handling of complaints;

9. The right to social rehabilitation;

10. The right to health and psychological recovery of the suffering experienced by the victim; 
11. Rights of victims and their families to get the ease of the judicial process;

12. The right to protection facilities for children who are homeless and/or under threat.

Of the twelve (12) the right type of organizing protection of set out in Chapter VI Implementation of Protection for Both Women and Children Child Protection Section covering Health Paragraph 1, Paragraph 2 of Education and Social Welfare Paragraph 3. While efforts to resolve violence against children set out in Chapter XII of the Protection of Women and Children from Violence, Trafficking and Exploitation transactions are carried out through several efforts include:

1. Preventing violence against women and children, including trafficking in persons;

2. Remove all forms of violence and exploitation of women and children;

3. Protect from discrimination against women and children, protection from neglect and other abuses;

4. Providing services to women and children victims of violence, the complainant and witnesses;

5. Facilitate and mediate on disputes households to realize the harmonious domestic unity and prosperity.

These efforts to be done by local governments, communities, families and the elderly. Of 4 (four) subject to the protection and settlement of violence against children, each carried out concretely by step:

\section{Protection and settlement of violence against children by local authorities:}

a. Implement policies protect women and children from violence, trafficking, and exploitation set by the government.

b. Setting policies, programs, and activities of the protection of women and children from violence, trafficking, and exploitation;

c. Cooperation in organizing the protection of women and children from violence, trafficking, and exploitation;

d. Provide infrastructure support implementation of the protection of women and children from violence, trafficking, and exploitation;

e. Allocate a budget for the organization to protect women and children from violence, trafficking, and exploitation appropriate fiscal capacity;

f. And supervise the protection of women and children from violence, trafficking, and exploitation.

g. In order to implement these policies, mayor designates action programs and activities of the protection of women and children, trafficking and ksploitasi in a local action plan as a basis for SKPD in implementing the protection of women and children from violence, trafficking, and exploitation. Regional Action Plan is part of the Medium Term Development Plan (RPJMD) and the provisions stipulated in the regulations over the mayor continued.

2. Protection and settlement of violence against children by organized society in the form of public participation. The role of such communities can prevent violence against women and children, trafficking and exploitation; provide information and/or reports of violence against women and children, trafficking and exploitation to law enforcement authorities or the authorities; participated in the handling of victims of violence, trafficking, and exploitation.

3. Protection and settlement of violence against children by family and/or parents who legally has the full responsibility to prevent all forms of violence and protect women and children as family members.

Then, after the completion of child abuse need to be set on violence against children that will not recur in the future. In the Rule of Regional Bekasi City Number 12 Year 2012 this provision set out in article 44 S / d of article 50 which outlines contain To prevent violence against women and children, trafficking and exploitation of local government empowerment and awareness to families, parents, and the community by providing information, guidance and / or counseling. In addition to local government empowerment and awareness efforts such as increasing the number 
and quality of education, both formal and informal; opening of accessibility to education, training, funding, income generation, and social services; create employment for women; build participation and public awareness on the prevention of women and children from violence, trafficking and exploitation; build and supply a complete information system and easily accessible; networking and cooperation with law enforcement agencies, government officials, universities and NGOs engaged and/or care for women and children; and open a complaint post protect women and children from violence, trafficking, and exploitation. Universities and NGOs engaged and/or care for women and children; and open a complaint post protect women and children from violence, trafficking, and exploitation. Universities and NGOs engaged and/or care for women and children; and open a complaint post protect women and children from violence, trafficking, and exploitation.

In the handling of child victims of violence can be said that community service is a front line that reporting to the police through Unit Women and Children (UPPA) and RPK or directly to the Integrated Service Center. At the center of this integrated service, steps are handling. Integrated Services Center is a functional unit that carries an integrated service for victims. Integrated Service Center itself can be a place called the shelter/safe house, RPTC, RPSAs, P2TP2A, and Integrated Service Center that is based in Police Hospitals and so on. Integrated service begins with the identification of victims to make sure someone is the victim of violence or not. This identification is done by conducting interviews with the victim in order to ascertain what assistance is needed by the victims. Does it require medical rehabilitation, social rehabilitation, legal assistance or directly sent back to the family or a substitute family?

Health rehabilitation mechanisms to follow the health care system as detailed in the minimum service standards for the handling of women and children victims of violence. If the victim requires medical rehabilitation, it can be handled in the clinic was able management of VAW/A. If the victim requires advanced medical rehabilitation services (specialist) may be referred to a hospital that has an integrated service (PPT). If not available PPT Hospital, the referral cases requiring specialist medical services can be done at the hospital vertically, hospitals, military police or private. When victims need social rehabilitation in which the victim suffered psychosocial and psychological disorders, the psychosocial team will provide counseling and therapy as needed. If the condition of either health or social victims has been declared recovered,

Repatriation performed at least when medical rehabilitation, social rehabilitation, and or legal assistance have been met. Repatriation is intended to restore the victim to the family or substitute family safely and securely. This repatriation can be assisted by the police, social workers/volunteers if necessary.

After repatriation carried out by the PPT will be made to the social reintegration ie return/reintegration of victims to the family/environment to improve the empowerment of the victim so that the victim can live life "normal" in society. At the time of this reintegration can do a variety of things such as follow-up counseling, follow-up treatment, vocational training, education, and self-employment assistance, legal assistance, where the entire process is carried out in the family or a substitute family? The purpose of all the interventions of identification, medical rehabilitation, social rehabilitation, legal assistance, repatriation, and social reintegration is done so more helpless victims according to their needs.

Technically field the process of handling the victims (Children) of the act of violence carried out by the mechanism:

1. Victims who come alone, through the referral process or obtained through the outreach conducted identification process that includes screening, assessment and intervention plans according to the needs of victims.

2. If the victim if the victim was injured then the victim as soon as possible given that the health rehabilitation services include non-critical, semi-critical services and critical services in accordance with the condition of the victim. The medical record must contain the results of the examination of victims as possible as it can be used as material justice.

3. If the victim does not have physical injuries and identified need counseling for recovery psychic, then the victim entered the stage of social rehabilitation which includes the social contract is an agreement with the 
victim's consent to get social services, counseling early, extended counseling, clinical assessment, psychosocial therapy, mental and spiritual guidance, counseling, home visit and socialization and referral if necessary. If the victim is a child then the consent of the victim or the victim companion is not required.

4. If the victim requires legal aid is carried out after the process of medical rehabilitation, social rehabilitation, or can be given if the victim does not require rehabilitation. Legal aid granted from the implementation process of the investigation in the police, the prosecution in the attorney through the process of examination in court. Including legal assistance for victims obtain restitution TPPO processed by police includes material and non-material loss suffered by the victim, collected and attached together with the case file.

5. Victims were repatriated from abroad and within the country to the area of origin or the country of origin or the family or a substitute family, the wishes and consent of the victim, to support the protection and fulfillment service needs. Under the category of victims of violence are divided into domestic and cross border/domestic. PPT assistance to victims who have received the service and will be sent back to the family or a substitute family.

6. In the case of the victims of violence come from the State immediately adjacent to Indonesia, the role of the PPT border after the handover of the Indonesian representatives abroad, then the victim directly provided services by PPT after the PPT to coordinate with relevant agencies for repatriation of victims to their home area.

7. The last process of the service for the victims is the social reintegration process, in which the victims were collected by family or surrogate family as well as aligned to the victim can be accepted back by their families and communities. In this process, including the economic and social empowerment and debriefing skills in order to produce economic, educational provision for victims who are still in school and interrupted due to being victims as well as their monitoring and advanced guidance.

8. PPT role in the social reintegration is monitoring and evaluation and reporting treatment for victims and coordinate with agencies / social services and agencies / other related agencies.

9. In order to achieve the required order of administration and data collection forms every stage of the service process. Each service agencies to use a standard form which has been agreed in order to facilitate the recapitulation.

10. Overall, this process should be based on services and cannot be separated from the principles of Respect for Human Rights (HAM), to avoid gender bias and carry out the fulfillment of child rights.

While the types of services that can be provided in the mechanism for addressing child victims of violence is covering Complaint/Identification, Services, and Legal Aid. Technical implementation complaint Service/identification is the first activity carried out in the handling of child victims of violence to obtain information or to dig the data required in order to aid and this step is a step that will affect the success of the next steps. Beginning of Complaint victim identification, the identification process can occur because of the participation of the community who came and received at the service stations of victims of violence. (Integrated Services Center, Shelter, P2TPA, Shelter, RPSAs, RPTC, Trauma Center, Institute for Family Welfare Consultation (LK3), etc.). Having been informed of their child victims of violence, officers immediately record the identity of the child in full, in accordance with a predetermined form. Determining the type of violence experienced, based on the information/observations obtained, it can be determined whether the situation of children experienced physical or psychological. Determining the type of service needed, provide referrals in accordance with the identification of violence. If the child gets physical and psychological violence are referred to obtain health rehabilitation, psychosocial, or legal assistance. Determining the type of service needed, provide referrals in accordance with the identification of violence. If the child gets physical and psychological violence are referred to obtain health rehabilitation, psychosocial, or legal assistance. Determining the type of service needed, provide referrals in accordance with the identification of violence. If the child gets physical and psychological violence are referred to obtain health rehabilitation, psychosocial, or legal assistance. 
Recommendations Advanced Services, the results of assessments and treatment recommendations advanced by the referring PPT, the PPT officers provide recommendations care interventions with the aim to establish a follow-up measure of the best in the fulfillment of victims' rights. Coordination with related parties, after the recommendation of advanced services and woke up an agreement with the victim; the officer contacted the advanced service agencies to coordinate the next steps. Administrating the process of identification of the service, the result of the identification of the complaints put in Record Book Cases and administered together with supporting documents and put in a computerized database system.

While the technical implementation of legal services is a series of activities related to the handling and protection of children victims of violence in the legal field, ranging from the level of the investigation in the police, the prosecution in the prosecutor's office, and the inspection process in court until their legal certainty. Legal services provided in the framework of the fulfillment of the rights of victims and/or witnesses and are integrated with other services.

The legal services performed by lawyers, paralegal / legal assistant, police, prosecutors, judges, and other legal services providers. The shape of the legal services includes but are not fully include the provision of legal advice, legal assistance, exercise the power, represent, assist, defend, and perform other legal actions for the benefit of another law, in accordance with the provisions of the legislation in force. Steps ministry:

1. Placing a child and witness/complainant in the special service to provide security and comfort.

2. Ascertain whether children accompanied by parents, social workers, NGOs, and lawyers.

3. Taking the child information as outlined in the dossier (BAP).

4. The gathering of evidence related to the violence experienced by children.

5. Issuing a letter of request for a medical examination and a post mortem or post mortem et Psikiatricum (VEP).

6. Coordinate with relevant agencies for repatriation of victims to family or a substitute family.

7. Coordinate with prosecutors and issue a Notice of Commencement of Investigation (SPDP).

8. Publishes Notice of Development of Results of Investigation (SP2HP) to the complainant/family/ companion to determine the progress of the case.

9. Handed over to the prosecutor's case file.

10. To coordinate with social services/department of education/support NGOs and other agencies to provide assistance to child victims of violence, both in the process of examination in court and outside the court.

11. Appoint an officer who has a child's perspective.

12. Determination of the hearing schedule by considering the learning process of children who are still in school.

13. To examine the child in the courtroom by not using toga.

14. Holding the trial in the courtroom with a persuasive way to avoid the child.

15. Avoid children to suffer further trauma.

16. If the child's psyche is not possible, then the examination of the child in the courtroom.

17. Is the last resort and can be reached the other examination as stipulated in the law.

18. For the case of child victims of human trafficking crime, the prosecutor coordinating with the victims or their families regarding the demands of restitution when it is cooled by child victims of violence or their families.

19. Provide a copy of the letter of transfer of cases to the child victims of violence/reporter/family/companion.

B. The Existence of Bekasi City Regulation No. 12 the Year 2012 In The Completion Of Comprehensive Violence In Children The Days Coming

It should be understood the existence of legislation always refers to the theories Groundnorm and Stufenbau theory which meant constantly shaped hierarchies regulation of most normative to contain norms of technical implementation. Aside from being Norma technical implementation, where regulation is also a major pillar overarching realization of regional autonomy. Regulation districts/cities have characteristics that are set, particularly 
regulator relationship between local government, local communities, and stakeholders such as the local business world. Regulation of the district/city is not merely regulated matters concerning the political, social and cultural, but also the local economy.

Since 2000, through the MPR Decree No. 11l/MPR/2000 on the Sources of Law and Rules of Order Legislation, the type of local regulation has officially become a source of law and entered in the sort order legislation. In Article 3, paragraph (7) Tap is confirmed that the regulatory environment is regulation to implement the rule of law on it and accommodate the particular conditions of the area concerned. Then Emitter Article 4 paragraph (1) shall, in accordance with the sort order for this legislation, then any lower level rule of law must not conflict with higher legal regulations Iebih.

Local regulations may actually have to meet the league aspects, juridical, philosophical, and sociologist. Often the local regulations sociologist ignores this aspect, the laws in force in the community, and because it does not see the potential and characteristics of the community, the implementation of regulations much disturbed. This is what causes most of the regulations in question, contrary to the rules generally higher, also there is an overlap between the central and local policies as well as the overlap of the financing. Theoretically, the sort order for the legislation to be associated with the teaching of Hans Kelsen on Sfufenbau /des Rechta's The hierarchy of law with a core that rule of law is an arrangement in stages and any rule of law that is lower bersumberdari rule higher (Manan 2004 ).

Furthermore in order to achieve legal certainty Position regulations should Bekasi City of Regional Regulation No. 12 of 2012 on top of legislation covering Act No. 23 of 2002 on Child Protection, Law of the Republic of Indonesia Number 21 Year 2007 on Combating Trafficking people, Candies of Women Empowerment and Child Protection of the Republic of Indonesia Number 02 Year 2010 on the National Action Plan for the Prevention and Handling of Violence Against Children, Candy of Women Empowerment and Child Protection of the Republic of Indonesia Number 02 Year 2011 on Guidelines for Handling Children Victims of violence must not be contradictory. In principle, the position of Regional Regulation No. 12 Bekasi City 2012 adheres to the principle: Law of the Republic of Indonesia Number 21 Year 2007 on Combating Trafficking in Persons, Candies of Women Empowerment and Child Protection of the Republic of Indonesia Number 02 Year 2010 on the National Action Plan for the Prevention and Handling of Violence Against Children, Candy of Women Empowerment and Child Protection of the Republic of Indonesia Number 02 Year 2011 on Guidelines for Handling Children Victims of violence must not be contradictory. In principle, the position of Regional Regulation No. 12 Bekasi City 2012 adheres to the principle: Law of the Republic of Indonesia Number 21 Year 2007 on Combating Trafficking in Persons, Candies of Women Empowerment and Child Protection of the Republic of Indonesia Number 02 Year 2010 on the National Action Plan for the Prevention and Handling of Violence Against Children, Candy of Women Empowerment and Child Protection of the Republic of Indonesia Number 02 Year 2011 on Guidelines for Handling Children Victims of violence must not be contradictory. In principle, the position of Regional Regulation No.12 Bekasi City 2012 adheres to the principle: Chewing of Women Empowerment and Child Protection of the Republic of Indonesia Number 02 the Year 2011 on Guidelines for Handling Children Victims of Violence must not be contradictory. In principle, the position of Regional Regulation No. 12 Bekasi City 2012 adheres to the principle: Chewing of Women Empowerment and Child Protection of the Republic of Indonesia Number 02 the Year 2011 on Guidelines for Handling Children Victims of Violence must not be contradictory. In principle, the position of Regional Regulation No. 12 Bekasi City 2012 adheres to the principle:

1. Legislation of higher social status can be used as a foundation or legal basis for legislation which are lower or under it.

2. Bekasi City of Regional Regulation No. 12 of 2012 must be sourced or legal basis darl legislation a higher level.

3. Fill or charge of Regional Regulation No. 12 Bekasi City 2012 should not deviate or berlentangan with legislation of a higher order.

4. Bekasi City of Regional Regulation No. 12 of 2012 can only be removed or replaced or amended by legislation which is higher or at least the equivalent. 
5. Rules and regulations of the same material, the latest rules should be applied, although not with the expressly stated that the old regulation was repealed. Other than that. The rules governing a more specialized material should take precedence over the legislation more generally.

From the above theory, if the position of Regional Regulation No. 12 Bekasi City in 2012 tested with the five principles above, the following is a description. Article $28 \mathrm{~B}$ (2) of the Constitution of the Republic of Indonesia Year 1945 mandates that "every child has the right to live, grow and expand and is entitled to protection from violence and discrimination". Therefore, parents, families, communities, governments and the State must make room for optimal child growth and the duty to protect from violence. Child's world is a world that can be enjoyed by children without violence, without fear so that children are able to express and actualize themselves positively in various forms.

This is a fundamental right for children is guaranteed by the constitution as stated in Article 13 paragraph (1) of Law No. 23 of 2002 on the Protection of the Child states that every child while in the care of a parent, guardian, or any other party responsible for the care, the right to protection from discrimination, exploitation, both economic and sexual abuse, neglect, cruelty, violence and abuse, injustice and mistreatment act. The next in Article 15 of Law No. 23 of 2002 on Child protection mandates that every child are entitled to protection from abuse in political activities, involvement in armed conflict, involvement in social unrest, involvement in the event that violence and involvement in the war.

Of the two articles above shows that our country has the policy to protect children from various forms of violence. Anyone not allowed to commit acts of violence against children for any reason, and should play a role in providing protection of children against violence. In addition to in Article 62 of Law No. 39 of 1999 on Human Rights mandates that every child is entitled to health services and social security as appropriate, in accordance with the physical and mental needs spiritual. In addition to Law Number 23 of 2002 on Child Protection, Law No. 23 of 2004 on the Elimination of Domestic Violence, and Law No. 21 of 2007 on the Eradication of Trafficking in Persons,

Furthermore, in order to realize and implement the regulatory provisions that are above the Bekasi City of Regional Regulation No. 12 of 2012 in resolving child abuse carried out by effecting all approach to child abuse by considering the completion of the concept and the development stage of completion of child abuse as mandated in Law Law No. 23 of 2002 on Child Protection, Law of the Republic of Indonesia Number 21 Year 2007 on Combating Trafficking in Persons, Candies of Women Empowerment and Child Protection of the Republic of Indonesia Number 02 Year 2010 on the National Action Plan for the Prevention and Handling of Violence Against Children, Chewing of Women Empowerment and Child Protection of the Republic of Indonesia Number 02 Year 2011 on Guidelines for Handling Children Victims of Violence.

The concept of the legislation above the law have become the basis for the development and implementation of protection and settlement of violence against children by the Rules of Regional Bekasi City No. 12 of 2012, which aims to build a government initiative the district / city directed to the transformation of the concept of child rights into policies, programs, and activities to ensure the fulfillment of the rights of children in the district / city. Completion of the development phase of violence against children begins with the stages of preparation, planning, implementation, monitoring, evaluation, and reporting. The important thing to note is that in every stage of these activities shall take into account the views of children obtained through the consultation of children. The child consultation can be done for example through consultative meetings,

To be able to measure the regional Regulation of Bekasi City No. 12, 2012 in order legislation National so as to finish and fill the void of legal norms that have not been dealt with comprehensively in legislation on it is to look at Chapter VI Implementation of the Protection of Women and Children Part Two Child Protection paragraph 1 samapai with paragraph 3 of article 21 to article 30.

Health Article 21 paragraph 1 of Bekasi City Regional Regulation No. 12 of 2012 which mandates the Local Government shall provide facilities and organizes comprehensive health efforts for children in order to obtain optimal health status from inside the womb. Provision of health facilities and implementation of efforts to comprehensively supported by community participation. Comprehensive health efforts include promotive, preventive, curative, and 
rehabilitative good for basic healthcare and referral. Comprehensive health efforts conducted free of charge for people with disabilities, street children, children who are victims of violence, abduction, abandoned children, HIV / AIDS, and sexually exploited economically, trafficking, drug abuse, alcohol, psychotropic.

Kids are guaranteed to receive exclusive breastfeeding from his mother are true and fair. To guarantee the implementation of Child rights get milk from the mother, the Government is obliged to facilitate infrastructure in places where breastfeeding minimal public services. For children from poor families and provide assistance to facilitate the Government of nutrition or food supplements to improve the health of children. Comprehensive health efforts have done gradually adapted to the local financial capacity. Here are the indicators of achievement of these rules:

1. The availability of health services for child victims of violence in health centers and hospitals are easily accessible;

2. Implementation of medical referral, medico legal and psychosocial for child victims of violence;

3. Availability of data disaggregated cases of child victims of violence in health centers and hospitals;

4. The development of management guidelines and standards of care cases of violence against children;

5. Strengthening health rehabilitation program management services for violence against children;

6. Increasing the capacity of human resources in health rehabilitation services;

7. The availability of medical rehabilitation services to children victims of violence;

8. The improved system for recording and reporting of violence against children;

9. Supported availability of funds for health rehabilitation services in cases of violence against children through Jamkesnas, budget or other funding sources.

Education Paragraph 2 of Article 24 of Bekasi City Regional Regulation No. 12 of 2012 mandates the Local Government guarantee the implementation of the compulsory education program of at least nine (9) years for all children. Implementation of compulsory education program supported by the participation of the community and the business world. Parents and families are required to provide the widest possible opportunity to the children according to the ability of the child to education. Education providers prohibited from issuing any children from educational institutions without any guarantee of continuity of children's education. Children with special needs are given equal opportunities and accessibility to obtain regular education and special education. Children in conflict with the law,

Local Government, the public and private sectors organized Post Early Childhood Education (ECD) is integrated into every RW. Post Implementation of Early Childhood Education (ECD) by the regional government carried out in accordance with local financial capacity. For children aged 7 (seven) to under 18 (eighteen) years old who have not completed their formal education can be educated through informal education unit: a. Study Group Package A similar Elementary School and Elementary School; b. Study Group Package B equivalent for the First Secondary School and MTs; c. Package C Learning group similar High School and Madrasah Aliyah; d. Vocational Study Group Package C equivalent Vocational High School and Vocational Madrasah Aliyah. Here are the indicators of achievement of these rules:

1. Implementation of compulsory study program of at least nine (9) years for all children in the area of Bekasi city;

2. Tersosilisasikannya and increased awareness of parents and family-related policies to provide greater opportunities to the children according to the ability of the child to education.

3. Availability of infrastructure in Bekasi City Region for Children with special needs in regular education and special education as well as children who become pregnant outside of marriage and child victims of HIV / AIDS;

4. Facilitating For children aged 7 (seven) to under 18 (eighteen) years old who have not completed their formal education can be educated through informal education unit: a. Study Group Package A similar Elementary School and Elementary School; b. Study Group Package B equivalent for the First Secondary School and MTs; c. Package C Learning group similar High School and Madrasah Aliyah; d. Vocational 
Study Group Package C equivalent Vocational High School and Vocational Madrasah Aliyah. Regional governments are also obliged to provide adequate facilities and infrastructure in the learning process and facilitate both formal and informal education organized by the government.

5. Establishment of a reference unit with the participation of children learning the underlying charge of child protection in the subjects/courses at all levels of education and teaching code of conduct for educators/teachers, prison officers, and parlors.

In paragraph 3 of article 30 of the Social Welfare Bekasi City, Regional Regulation No. 12 of 2012 mandated the Implementation of social welfare for children is the duty of Local Government with the involvement of the community, business, and family. The social organization of the child is given to a. children in conflict with the law; b. economically exploitative child and sexual abuse; c. Child victims of trafficking; d. child victims of drug abuse; e. Child victims of HIV/AIDS; f. child victims of abduction; g. children who do not have parents or family; h. and neglected children; i. Street children; j. child victims of violence; k. Child victims of disasters; 1 . children with disabilities; $m$. children who have ill-treatments. Implementation of child protection in the form of social welfare services: a. social counseling, mental and spirituaal; b. social rehabilitation; c. accompaniment; d. empowerment; e. social assistance; f. legal assistance and/or; g. reintegration of children in the family. Forms of participation of the community and the business world in the implementation of child protection, among others, can be: a. the provision of safe houses and shelters; b. establishment of integrated child care centers; c. the establishment and management of the orphanage; $d$. the establishment of a rehabilitation center child victims of drug abuse; e. providing assistance to children in conflict with the law; f. awarding scholarships; g. provision of health care costs; h. Children's Playground provision; i. actively supervise children to activities that are not in accordance with the norms prevailing in society; $j$. forms of public participation and other business related to the implementation of child protection. Here are the indicators of achievement of these rules:

1. In Implementation of social welfare for children due to violence against children has also involved the community, businesses, and families in the area of Bekasi city.

2. Has provided services to the Institution/department/ work unit area in Bekasi City area that serves aspects include:

a. Children in conflict with the law;

b. Economically exploitative child and sexual abuse;

c. Child victims of trafficking;

d. Child victims of drug abuse;

e. Child victims of HIV / aids;

f. Child victims of abduction;

g. Children who do not have parents or family;

h. And neglected children;

i. Street children;

j. Child victims of violence;

k. Child victims of disasters;

1. Children with disabilities;

m. Children who have ill-treatments.

3. Organizing and implementation of such services has been done effectively through a number of activities by the Department / Institution / Regional Work Units / NGOs / Civil Society Organizations / Foundations in Bekasi City area that includes:
a. Social counseling, mental and spiritual;
b. Social rehabilitation;
c. Accompaniment;
d. Empowerment; 
e. Social assistance;

f. Legal assistance and/or;

g. Reintegration of children in the family

h. The provision of safe houses and shelters;

i. Establishment of integrated child care centers;

j. The establishment and management of the orphanage;

k. The establishment of a rehabilitation center child victims of drug abuse;

1. Providing assistance to children in conflict with the law;

m. Awarding scholarships;

n. Provision of health care costs;

o. Children's playground provision;

p. Actively supervise children to activities that are not in accordance with the norms prevailing in society;

q. Forms of public participation and other business related to the implementation of child protection.

4. Providing services social rehabilitation, repatriation, and social reintegration widely for victims of violence against children.

5. He has done the development of case management guidelines and strengthens the capacity of the ministry of social rehabilitation, repatriation and reintegration

6. He has done to raise the active participation of civil society in providing support for the social reintegration of child victims of violence.

7. He has done the development of alternative patterns of social rehabilitation, repatriation and social reintegration based on cultural values, customs and traditional practices in a society those accords with child rights-based child protection.

8. Has a budget allocation specifically to develop rehabilitation services, repatriation and social reintegration of victims of violence against children.

Thus an earlier description of Existence Bekasi City Regional Regulation No. 12 of 2012 in the settlement of violence on children. The norms contained in these regulations has been comprehensively implementing the embodiment of legislation related above and has also had a system of monitoring and evaluation is a measuring tool to test the effectiveness of the implementation of the Regional Regulation of Bekasi No. 12 of 2012 concerning the Prevention and Handling of Violence Against child. Dimensions of the impact of the implementation of Bekasi City Regional Regulation No. 12 of 2012 be used as an indicator of completion and the completion of the evaluation effort of violence against children. Indicators specified in the monitoring and evaluation tools will be used as benchmarks for achievement testing program. Monitoring is used to determine and provide the feedback implementation process of the implementation of Bekasi City Regional Regulation No. 12 of 2012 Prevention and Treatment of Child Abuse. Monitoring is conducted periodically and integrated by the Bekasi City Government Task Force for Prevention and Treatment of Child Abuse. Evaluation is a tool to assess the results of the implementation of Bekasi City Regional Regulation No. 12 of 2012 Prevention and Treatment of Child Abuse as a repair base for the elimination of violence against children. This evaluation is carried out every year. Monitoring is conducted periodically and integrated by the Bekasi City Government Task Force for Prevention and Treatment of Child Abuse. Evaluation is a tool to assess the results of the implementation of Bekasi City Regional Regulation No. 12 of 2012 Prevention and Treatment of Child Abuse as a repair base for the elimination of violence against children. This evaluation is carried out every year. Monitoring is conducted periodically and integrated by the Bekasi City Government Task Force for Prevention and Treatment of Child Abuse. Evaluation is a tool to assess the results of the implementation of Bekasi City Regional Regulation No. 12 of 2012 Prevention and Treatment of Child Abuse as a repair base for the elimination of violence against children. This evaluation is carried out every year.

Violence against children is a violation of human rights and also against the law because it is administered in a comprehensive manner through legislation began to level the Act until the implementing regulations at the local 
government level, especially the city of Bekasi City. Bekasi City Regional Regulation No. 12 of 2012 Violence on Children is needed as a spur to all government agencies and the community to take responsibility to protect children from violence, whether perpetrated by the state, society, institutions/agencies as well as families and individuals. Completion, completion, and the elimination of violence against children through the pouring in the regulation of local regulations Bekasi is an effort in order to build the civilization of a nation that upholds human rights and dignity, in particular, the respect, fulfillment,

Post-ratification of Bekasi City Regional Regulation No. 12 of 2012 and has become effective than in order to realize this goal requires commitment and concern of the government and the entire community in implementing various programs have been poured therein.

\section{Conclusions and Recommendations Conclusion}

Exposure-based on previous chapters above, there are some things that can be drawn into the conclusions in this thesis:

1. The existence of Regional Regulation No. 12 Bekasi City 2012set out in Chapter XII of the Protection of Women and Children from Violence, Trafficking and Exploitation transactions are carried out through several efforts include:
a. preventing violence against women and children, including trafficking in persons;
b. remove all forms of violence and exploitation of women and children;
c. protect from discrimination against women and children, protection from neglect and other abuses;
d. providing services to women and children victims of violence, the complainant and witnesses;
e. facilitate and meditate on disputes households to achieve domestic unity harmonious and prosperous

2. Implementation of Regional Regulation No. 12 Bekasi City 2012 in the order of national legislation is real and is effective so as to finish and fill the void of legal norms are not regulated comprehensively in legislation thereon. To be able to measure the regional Regulation of Bekasi City No. 12, 2012 in order legislation National so as to finish and fill the void of legal norms that have not been dealt with comprehensively in legislation on it is to look at Chapter VI Implementation of the Protection of Women and Children Part Two Child Protection paragraph 1 until paragraph 3 of article 21 to article 30.

\section{Recommendations}

1. Presence Bekasi City Regional Regulation No. 12 of 2012 has made its laws and regulations can be implemented technically because of the norms contained in Bekasi City Regional Regulation No. 12 of 2012 are technical implementation and the level of implementation, but there are still shortcomings. In the regulation region is not seems the norm of the rule of law on minimum service standards (SPM) conducted by the Bekasi government for each type of service completion violence against children so that there is no standard benchmark to blame bureaucrats for the implementation of tasks and functions in the settlement of violence against children completely.

2. Regulations and policies at the district/city as Bekasi City Regional Regulation No. 12 of 2012 on expected line and harmonized with other legislation as an integral part of national law. Sometimes these regulations have an ideal set up Coordinate with the local government organs of state of other countries, for example, the Court but due to the court's own policies have resulted in the coordination was not optimal. For example, the justice sector is rarely associated with those responsible for social welfare services. The lack of quantity, capacity, and mandate social worker hamper the delivery of services to protect children. In other words, tertiary care services have yet to be part of the continuum of services that span the community and family environments.

\section{References}

Abdulkadir Muhammad, Hukum dan Penelitian Hukum, PT. Citra Aditya Bakti, Bandung, 2004. 
Abintoro Prakoso, Pembaruan system Peradilan Pidana Anak, Yogyakarta, Grafika, 2013.

Alimuddin, Penyelesaian Kasus KDRT (Kekerasan Dalam Rumah Tangga) Di pengadilan Agama, Bandung, Mandar Maju, 2014.

Andi Hamzah; Kamus Hukum, Jakarta, Ghalia Indonesia, 1996.

Bagir Manan, Teori dan Politik Konstitusi, Cetakan Kedua, Yogyakart, FH UII Press, 2004.

Cst Kansil, Kamus istilah Hukum, Jakarta, Gramedia Pustaka, 2009.

Johan Galtung, Studi Perdamaian: Perdamaian dan Konflik Pembangunan dan Peradaban, Surabaya, Pustaka Eureka, 2003.

Justin Sihombing, Kekerasan Terhadap Masyarakat Marjinal, Yogyakarta, Penerbit Narasi, 2005.

Kamus Besar Bahasa Indonesia, Jakarta, Balai Pustaka, 1990.

Kementerian Perencanaan Pembangunan Nasional, Badan Perencanaan Pembangunan Nasional (BAPPENAS), Rencana Aksi Nasional Perlindungan Anak 2015 - 2019.

Lexy J. Moleong, Metodologi Penelitian Kualitatif, Bandung, PT. Remaja Rosada Karya, 1991.

M. Magfur, Anatomi Kekerasan Manusia antara Entitas Mencinta dan Kematian dalam Pemikiran Pekikiran Revolusioner, Malang, Qaverroes Press, 2003.

M. Marwan dan Jimmy P, Kamus Hukum, Surabaya, Reality Publisher, 2009.

Republik Indonesia, Peraturan Daerah Kota Bekasi Nomor 12 Tahun 2012 tentang Perlindungan Perempuan Dan Anak

Republik Indonesia, Undang-Undang Dasar Tahun 1945

Republik Indonesia, Undang-Undang Nomor 35 Tahun 2014 tentang Perlindungan Anak

Ronny Hanitijo Soemitro, Metodologi Penelitian Hukum dan Jurimetri, Jakarta, Ghalia Indonesia, 1988.

Setyowati Irma, Aspek Hukum Perlindungan Anak, Jakarta, Bumi Aksara,1990.

Stephanie Delane, Melindungi Anak-anak dari Eksploitasi Seksual \& Kekerasan Seksual Dalam Situasi Bencana \& Gawat Darurat, ECPAT Internasional, 2002.

Sugiyono, Memahami penelitian Kualitatif., Bandung, Alfabeta. 2008. 